\title{
ANALYSIS OF VERTICAL DISPLACEMENTS OF THE ESPERANTO FOOTBRIDGE IN BYDGOSZCZ
}

\author{
Adam BUJARKIEWICZ ${ }^{1}$, Jarosław GAJEWSKI ${ }^{1}$, Tomasz JANIAK ${ }^{1}$, \\ Justyna SOBCZAK-PIĄSTKA ${ }^{1}$, Jacek SZTUBECKI ${ }^{1}$, Rafał TEWS ${ }^{1}$ \\ ${ }^{1}$ University of Technology and Life Sciences in Bydgoszcz, Bydgoszcz, Poland
}

\begin{abstract}
The subject of the research is a footbridge across the river Brda in Bydgoszcz. The measurements of the footbridge displacements with the test load were undertaken. The paper presents the results of the measurements and compares them with the theoretical results obtained using the finite element method (FEM). On this basis, discrepancy between actual work of the structure and numerical simulations was found. Attempt to explain the reasons for the observed differences and direction of further research were included in the conclusions.
\end{abstract}

Keywords: cable-stayed bridge, displacements, FEM model

\section{INTRODUCTION}

The Building Law Act [7] imposes an obligation on a structure owner or user to use the structure in accordance with the intended use and environmental protection requirements, and to keep it in proper technical and aesthetic condition. Pursuant to Art. 62, section 1 of the Act [7], structures - when used - should be periodically inspected by the owner or administrator every year and every five years. During such inspections, a visual assessment is the main method applied.

${ }^{1}$ Corresponding authors: University of Technology and Life Sciences in Bydgoszcz, Faculty of Civil and Environmental Engineering and Architecture, Al. prof. S. Kaliskiego 7, 85-796 Bydgoszcz, Poland, tel. +48661567541, e-mail: jaceksz@utp.edu.pl 
For larger structures and structures of a more complex design, e.g. bridges, the visual method may be useful only at the first stage of inspection. At later stages, more advanced methods shall be used that allow more accurate and unambiguous determination of the technical condition of a structure [2, 4, 6]. A basic symptom of unfavourable phenomena occurring in buildings are their excessive displacements. They are monitored with a series of measurements of a network of measuring and control points established on the facility [5]. In order to facilitate professional and objective technical condition assessment of bridges, an example of using geodetic displacement measurement in technical diagnosis of existing bridges has been presented in this paper. The study has been conducted on the Esperanto footbridge crossing the Brda river in Bydgoszcz. Results of performed control measurements have been compared with data obtained from a theoretical model.

\section{DESCRIPTION OF THE SUBJECT OF STUDY}

The subject of study was the Esperanto footbridge in Bydgoszcz. It is perpendicular to the Jagiellońska street and parallel to the Krakowska street, and is a crossing on the Brda river designed for passers-by and cyclists. It connects the Skrzetusko and Babia Wieś (where the "Łuczniczka" Sport, Show, and Fair Arena is located) districts. The view of the footbridge has been presented in Photo 1.

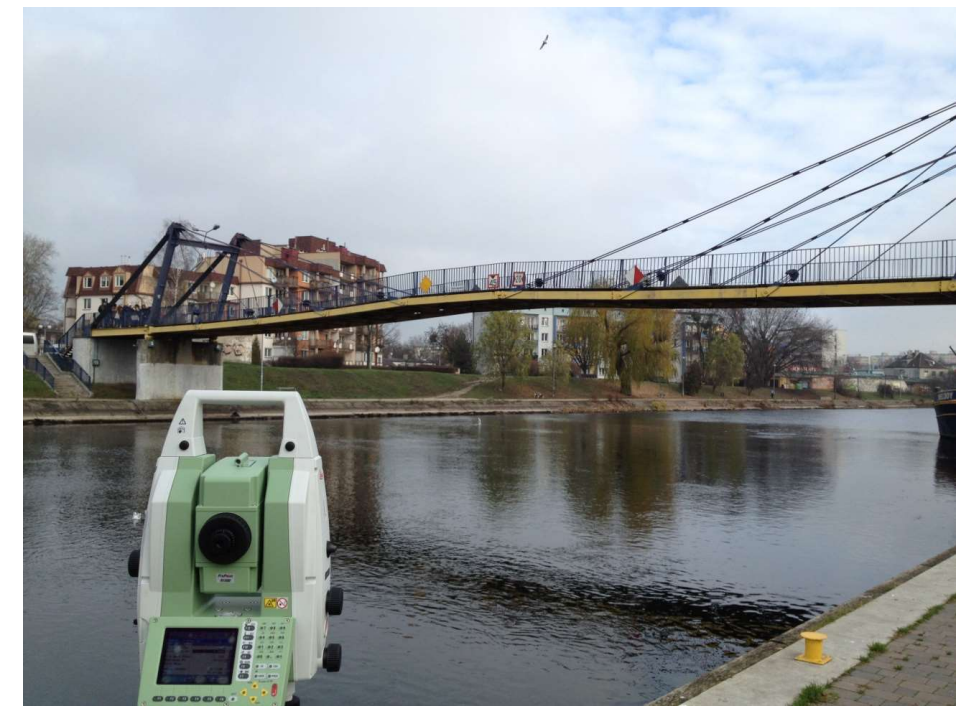

Photo 1. View of the footbridge 
This location of the structure makes it very intensively used, also by somewhat numerous groups of attendees of artistic and sport events. Until 1970, a ferry crossing was operating at this place. The footbridge had been designed by $\mathrm{PhD}$ Tadeusz Kabat in 1977, and built by BPBP company in 1979 [3]. The administrator of the structure is Management of Urban Roads and Public Transport in Bydgoszcz.

The footbridge is a three-span construction with a suspended steel structure. It consists of spans of the following lengths: $8.00 \mathrm{~m}+50.0 \mathrm{~m}+8.0 \mathrm{~m}$ (Fig. 1). Extreme spans are placed entirely above the riverbanks and the $50.00 \mathrm{~m}$ span is the main span. The footbridge has two intermediate supports placed at the edges of the banks and founded on piles. The upward pulling extreme supports are founded on wells and connected to the span structure with bolts. Extreme spans of the footbridge were designed as spans freely supported by reinforced concrete supports. The central span consists of eight segments, each $5.5 \mathrm{~m}$ long, and one central segment that is $6 \mathrm{~m}$ long. The segments are connected with joints and hanged on stay cables attached to the pylon top. The central segment and the rightbank pre-central segment are connected in a way that allows longitudinal movement. Steel pylons are inclined toward the central span at an angle of approx. $65^{\circ}$ from the horizontal plane and supported by intermediate supports using joints, whereas their heads are connected with extreme supports using stays. Total deck width is equal to $4.10 \mathrm{~m}$, the width between handrails is equal to $3.40 \mathrm{~m}$ [survey from 1992].

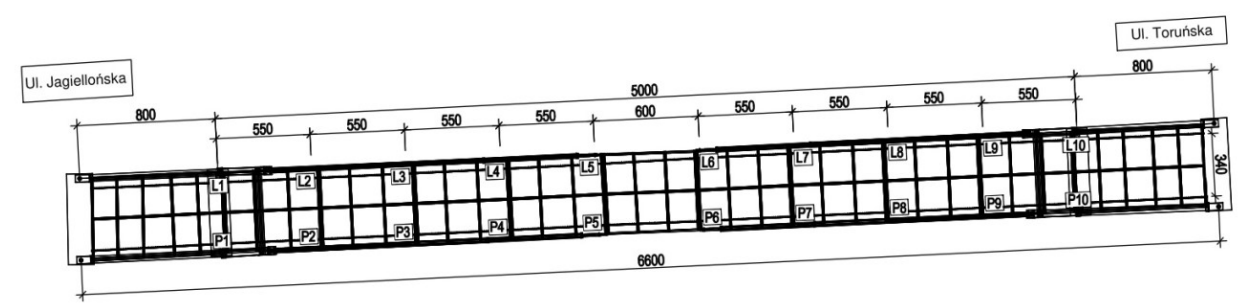

Fig. 1. Plan view of the footbridge

\section{METHODS}

\subsection{Measurement of vertical displacements in the footbridge}

In the course of the study, measurements of vertical displacements in the footbridge were performed for several different load application points. The load was applied using a pallet jack with a concrete brick placed on top of it. The total weight of the set was $1500 \mathrm{~kg}$. The load was statically applied in places where footbridge segments connect. 
Measurements were performed with the Leica TDRA6000 laser station (Photo 2) from two points located at footbridge abutments using the trigonometric method. The device is able to provide accurate measurement to 1.5 " RRR prism that allows determining vertical displacements with a $0.2 \mathrm{~mm}$ accuracy [1].

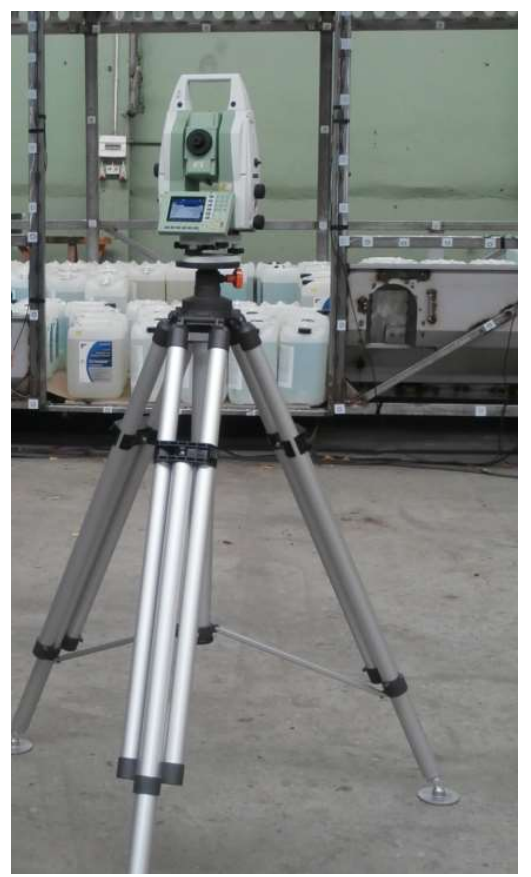

Photo 2. Coordinate laser station of the Leica brand, model TDRA 6000

Control points were placed at the outer edges of footbridge spans, above stay cable fixing points. Arrangement of control points and load application points has been presented in Fig. 1 and Fig. 2. Control points on the left lane of the footbridge were labelled with the letter L, those on the right lane - with the letter P, and load application points were labelled with letters A through $\mathrm{H}$. Movements of points were recorded from two positions located outside the studied structure, placed on a sturdy foundation: from the $\mathrm{S} 1$ position for loads A through D and from the S2 position for loads $\mathrm{E}$ through $\mathrm{H}$.

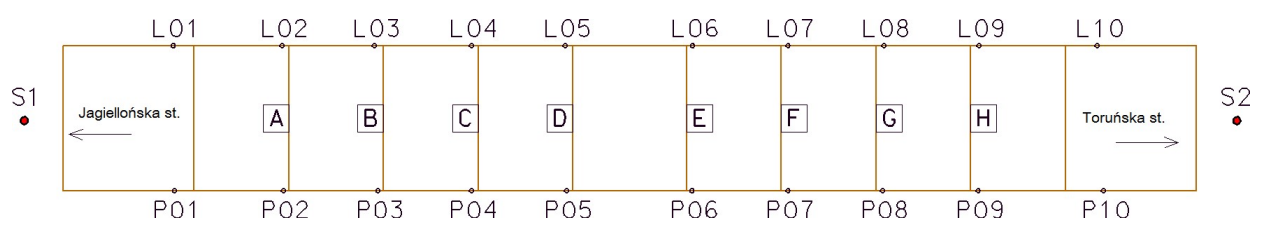

Fig. 2. Plan of arrangement of control points, measurement positions, and load application points 
The first displacement measurement had been a baseline measurement of the footbridge without loads. Subsequently, loads were applied to the footbridge by positioning the jack at points indicated in Fig. 2 and the obtained measurement results were recorded.

\subsection{Modelling the structure using the finite element method}

The next stage of the study was to develop a model of the structure using the finite element method (FEM). Based on this model, displacements of control points described in section 3.1 were determined. The load pattern adopted in the FEM model corresponded to loads used in geodetic measurements. Results obtained from calculations based on the theoretical model were compared with results of geodetic measurement.

It is worth noting that numerical models enable to analyse not only the state of displacement but also the state of stress, which is important from the viewpoint of structure safety. FEM model created based on the footbridge structure survey has been shown in Fig. 3. Due to symmetry of the footbridge, a flat numerical model covering half of the structure has been used

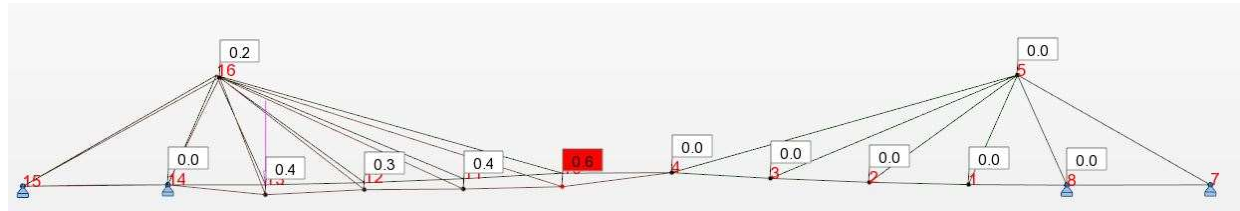

Fig. 3. FEM model of the footbridge structure

The load-bearing structure of the deck was modelled using beam elements connected with joints. Pylons, which are characterised by their high rigidity, were also modelled using beam elements. Due to their low rigidity, cables were modelled using elements that carry only tensile loads. Stays of the footbridge, which are characterised by higher rigidity than the aforementioned cables, were modelled using elements carrying both compression loads and tensile loads. The load pattern adopted in the FEM model corresponded to loads allowed for in geodetic measurements. An exemplary load system has been shown in Fig. 3.

\section{RESULTS}

\subsection{Results of measuring vertical displacements of the footbridge}

Vertical displacements of the footbridge were tested on 26 May 2017. To limit the effects of atmospheric conditions, all measurements were performed at night. 
Displacements of control points have been presented in Table 1. Graphical representation of displacements has been shown in Fig. 4.

Table 1. Vertical displacements of control points obtained during measurement [mm] A - H - load application points; L, P - sides of the footbridge; 01-10 - numbers of control points (cf. Fig. 2)

\begin{tabular}{|c|c|c|c|c|c|c|c|c|c|c|c|c|c|c|c|c|}
\hline & \multicolumn{2}{|c|}{$\mathbf{A}$} & \multicolumn{2}{|c|}{ B } & \multicolumn{2}{|c|}{ C } & \multicolumn{2}{|c|}{ D } & \multicolumn{2}{|c|}{$\mathbf{E}$} & \multicolumn{2}{|c|}{$\mathbf{F}$} & \multicolumn{2}{|c|}{ G } & \multicolumn{2}{|c|}{$\mathbf{H}$} \\
\hline & $\mathbf{L}$ & $\mathbf{P}$ & $\mathbf{L}$ & $\mathbf{P}$ & $\mathbf{L}$ & $\mathbf{P}$ & L & $\mathbf{P}$ & L & $\mathbf{P}$ & $\mathbf{L}$ & $\mathbf{P}$ & $\mathbf{L}$ & $\mathbf{P}$ & $\mathbf{L}$ & $\mathbf{P}$ \\
\hline 01 & 0.0 & -0.1 & 0.0 & 0.0 & -0.1 & 0.0 & -0.1 & 0.1 & -0.2 & -0.2 & -0.1 & -0.2 & -0.1 & 0.2 & -0.3 & 0.4 \\
\hline 02 & -0.5 & -0.8 & -0.4 & -0.6 & -0.4 & -0.4 & -0.5 & -0.5 & -0.4 & -0.3 & 0.2 & 0.4 & -0.4 & 0.1 & 0.0 & 0.2 \\
\hline 03 & -0.4 & 0.0 & -1.5 & -1.2 & -1.2 & -0.7 & -1.1 & -0.6 & 0.0 & -0.7 & -0.7 & -0.4 & -0.9 & -0.3 & 0.0 & 0.0 \\
\hline 04 & 1.1 & -0.6 & 0.5 & -0.8 & -3.3 & -2.7 & -2.6 & -2.1 & -0.7 & -0.5 & -0.5 & -0.4 & 0.0 & -0.3 & -0.1 & -0.2 \\
\hline 05 & -0.2 & -0.4 & -0.6 & -0.8 & -1.8 & -1.3 & -7.3 & $\mid-5.4$ & -2.3 & -1.9 & -0.7 & -0.8 & -0.4 & -0.5 & 0.0 & -0.5 \\
\hline 06 & -0.4 & 0.4 & -0.3 & 0.1 & 0.1 & 0.6 & -0.8 & 0.1 & -8.1 & -8.0 & -2.4 & -3.0 & -1.3 & -1.6 & -0.9 & -1.0 \\
\hline 07 & -0.2 & -0.2 & 0.3 & -0.1 & 0.5 & 0.4 & 0.0 & 0.4 & -3.0 & -3.3 & -3.7 & -4.1 & -1.2 & -1.3 & -0.6 & -0.7 \\
\hline 08 & -0.6 & 0.4 & -0.2 & -0.1 & -0.3 & 0.5 & -0.3 & 0.1 & -1.4 & -1.6 & -1.3 & -1.6 & -1.7 & -1.9 & -0.4 & -0.6 \\
\hline 09 & 0.5 & -0.3 & 0.3 & -0.4 & 0.7 & 0.1 & 0.4 & -0.5 & -0.8 & -0.6 & -0.6 & -0.3 & -0.6 & -0.4 & -0.7 & -0.5 \\
\hline 10 & 0.0 & 0.0 & 0.4 & 0.1 & 0.1 & 0.3 & 0.4 & 0.9 & 0.0 & -0.3 & -0.1 & -0.1 & -0.1 & -0.1 & 0.0 & 0.0 \\
\hline
\end{tabular}

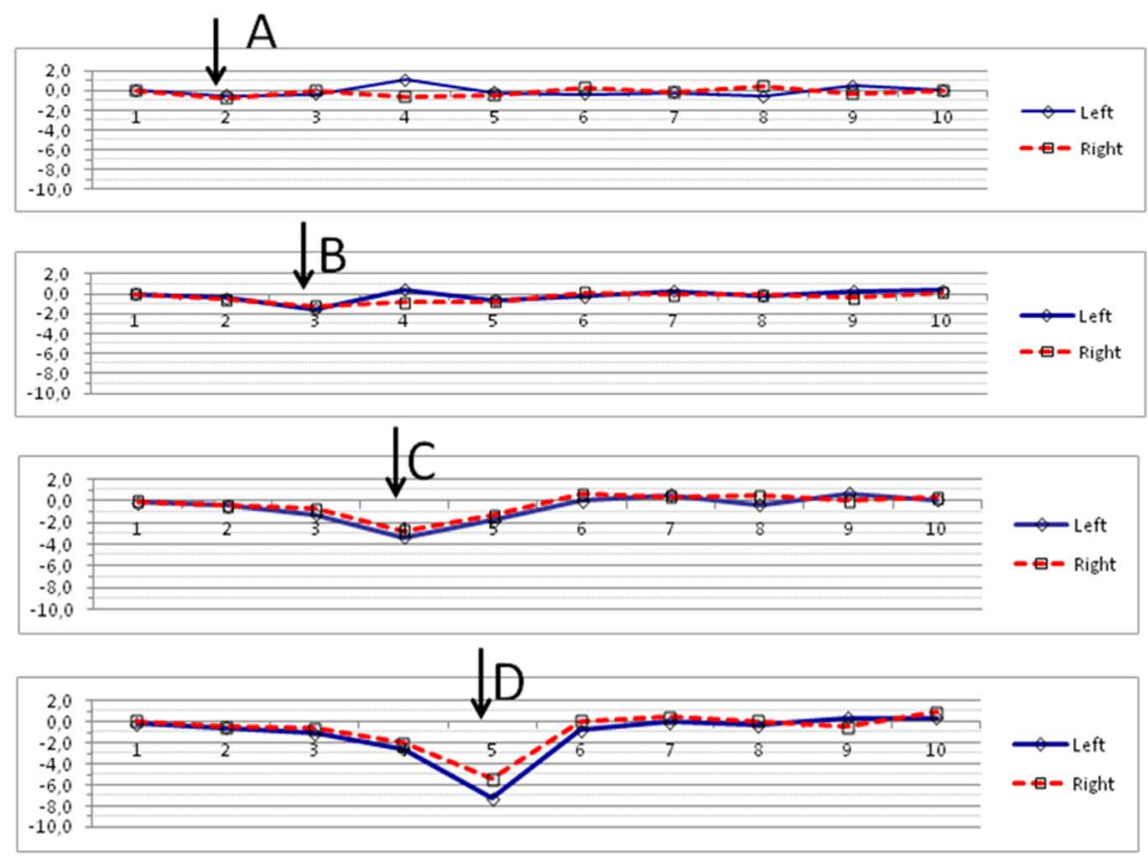




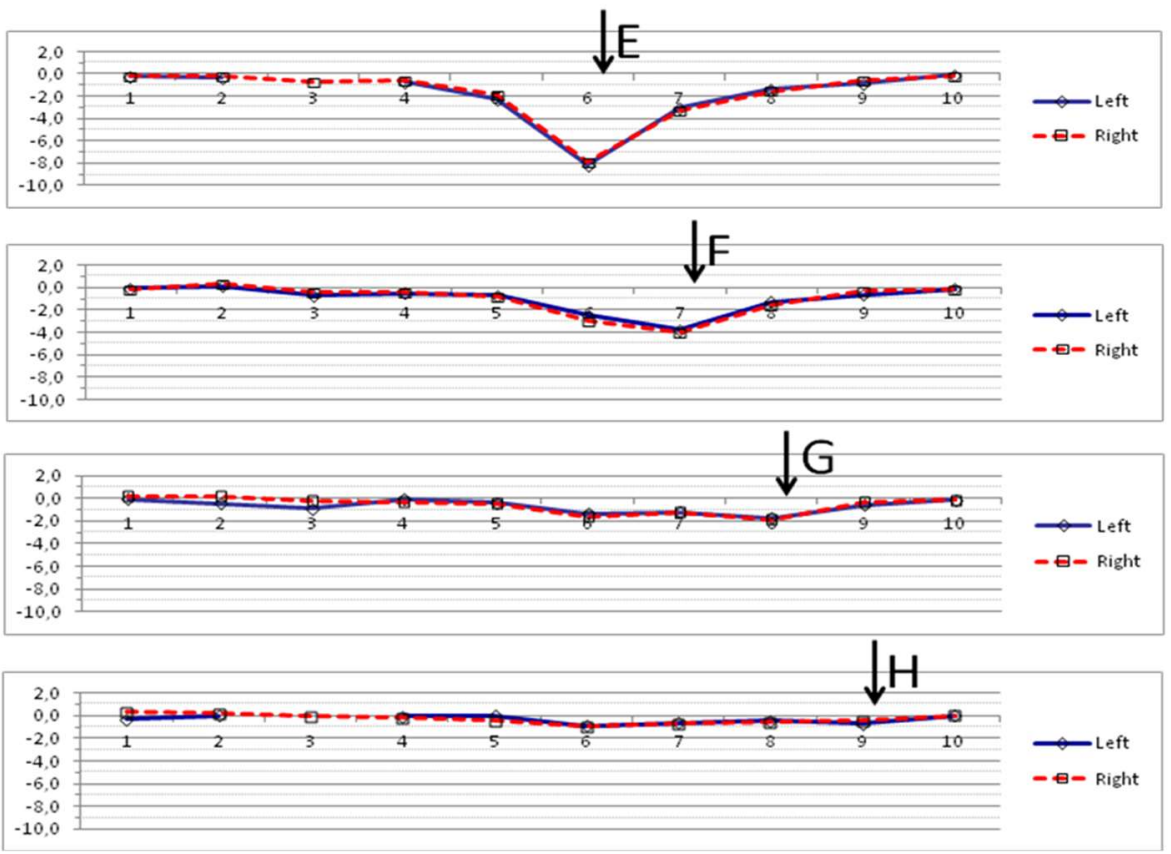

Fig. 4. Charts for recorded displacements of control points

The theoretical model of the footbridge was developed in the Autodesk Robot Structural Analysis software. Results of control point displacements have been listed in Table 2. Visual representation of displacements has been shown in Fig. 5.

Table 2. Vertical displacements of control points in the theoretical model A - H - load application points; L, P - sides of the footbridge; 01-10 - numbers of control points and corresponding numbers of nodes in the FEM model (in brackets) - cf. Fig. 2.

\begin{tabular}{|c|c|c|c|c|c|c|c|c|}
\hline \multirow{2}{*}{$\begin{array}{c}\text { Points } \\
\text { (nodes) }\end{array}$} & \multicolumn{9}{|c|}{ Load pattern } \\
\cline { 2 - 9 } & $\mathbf{A}$ & $\mathbf{B}$ & $\mathbf{C}$ & $\mathbf{D}$ & $\mathbf{E}$ & $\mathbf{F}$ & $\mathbf{G}$ & H \\
\hline $\mathbf{0 1}(\mathbf{8})$ & 0 & 0 & 0 & 0 & 0 & 0 & 0 & 0 \\
\hline $\mathbf{0 2}(\mathbf{1})$ & -0.38 & -0.31 & -0.42 & -0.56 & 0 & 0 & 0 & 0 \\
\hline $\mathbf{0 3}(\mathbf{2})$ & -0.27 & -1.39 & -0.98 & -1.19 & 0 & 0 & 0 & 0 \\
\hline $\mathbf{0 4}(\mathbf{3})$ & -0.39 & -0.87 & -2.61 & -2.05 & 0 & 0 & 0 & 0 \\
\hline $\mathbf{0 5}(\mathbf{4})$ & -0.51 & -1.15 & -1.88 & -5.39 & 0 & 0 & 0 & 0 \\
\hline $\mathbf{0 6}(\mathbf{1 0})$ & 0 & 0 & 0 & 0 & -5.45 & -1.88 & -1.16 & -0.52 \\
\hline $\mathbf{0 7}(\mathbf{1 1})$ & 0 & 0 & 0 & 0 & -2.05 & -2.62 & -0.87 & -0.39 \\
\hline $\mathbf{0 8}(\mathbf{1 2})$ & 0 & 0 & 0 & 0 & -1.2 & -0.99 & -1.4 & -0.27 \\
\hline $\mathbf{0 9}(\mathbf{1 3})$ & 0 & 0 & 0 & 0 & -0.57 & -0.43 & -0.31 & -0.38 \\
\hline
\end{tabular}




\begin{tabular}{|l|l|l|l|l|l|l|l|l|}
\hline $10(14)$ & 0 & 0 & 0 & 0 & 0 & 0 & 0 & 0 \\
\hline
\end{tabular}

a)

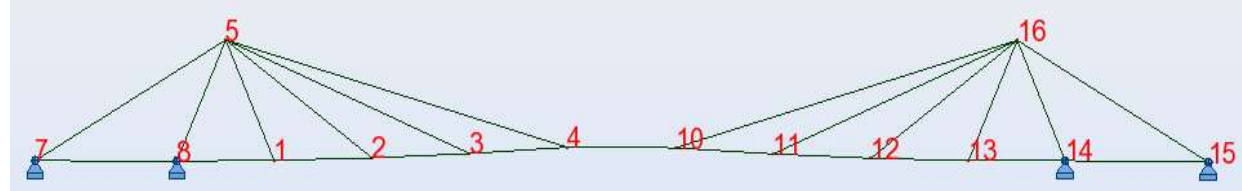

b)
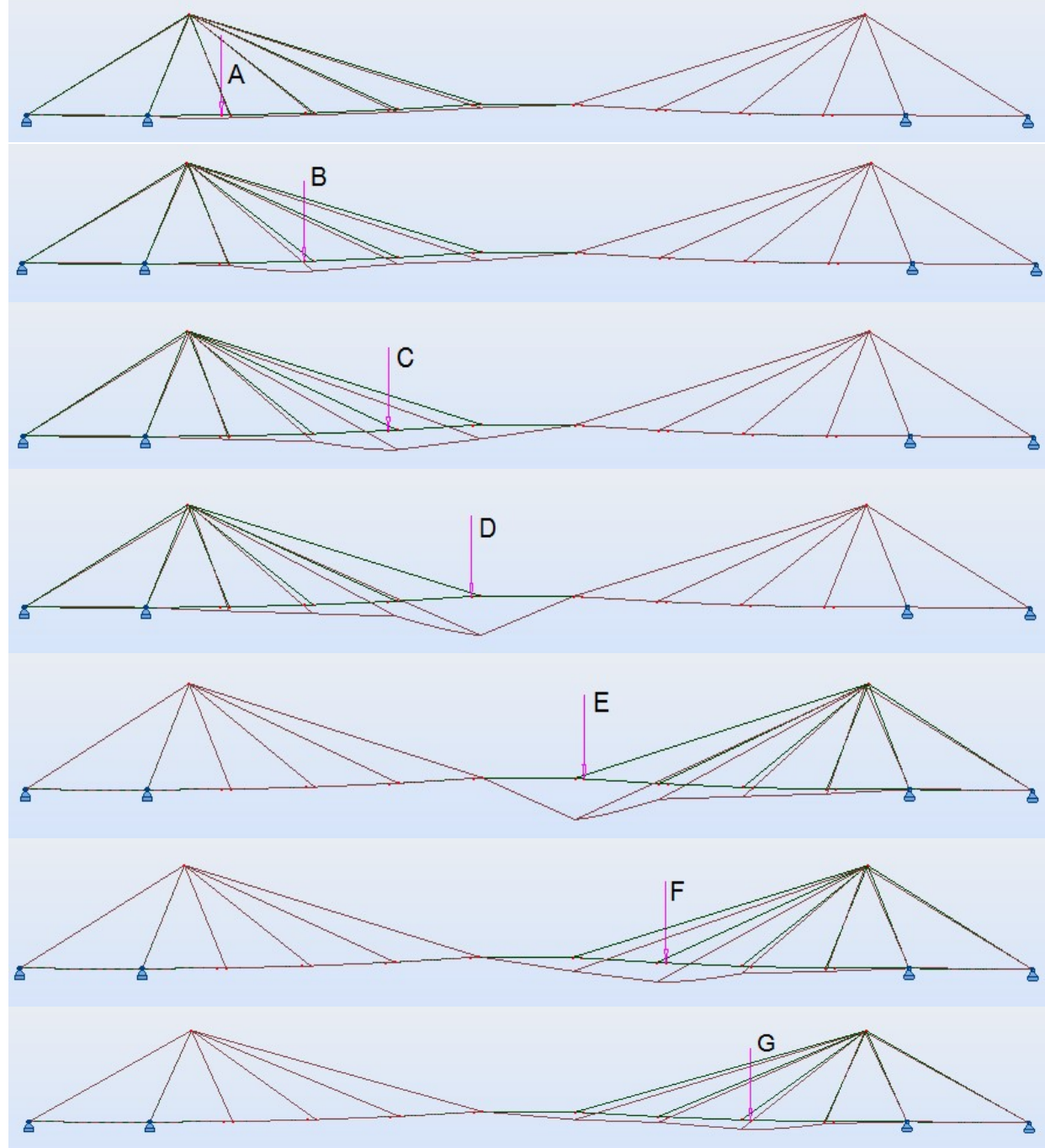


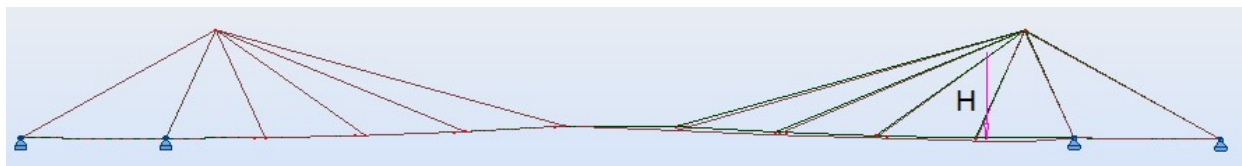

Fig. 5. Visual representation of displacements in the theoretical model, a) node numbers, b) displacement map for load patterns A through $\mathrm{H}$

\section{DISCUSSION}

In the FEM analysis, it was assumed that the structural system of the footbridge is symmetrical to the vertical plane drilled by the longitudinal axis. Analysis of calculated vertical displacement values listed in Table 2 leads to the conclusion that these displacements are nearly symmetrical to the plane perpendicular to the footbridge (the footbridge itself is not completely symmetrical to this plane as well).

Similar correlations should also be expected in case of measurement results. It became apparent that these results do not show symmetry in relation to any of the two vertical planes.

For symmetrical loads (placed along the longitudinal axis), a tendency of the footbridge segments to rotate around their axes has been observed, with rotation having different values in individual cross-sections. Rotation value $\varphi_{i}$ for section $i$ was calculated using the following formula:

$$
\varphi_{i}=\frac{w_{i}^{P}-w_{i}^{L}}{D}
$$

where $w_{i}^{P} \mathrm{w}_{\mathrm{i}}^{\mathrm{P} / \mathrm{L}}$ are values of displacement measured for the right edge of the footbridge, $w_{i}^{P} \mathrm{w}_{\mathrm{i}}^{\mathrm{P} / \mathrm{L}}$ are values of displacement measured for the left and $\mathrm{D}=3.55 \mathrm{~m}$, is the length of a line between measurement points perpendicular to the footbridge axis. Calculated rotation values have been listed in Table 3.

Table 3. Lateral rotation of the footbridge [0.001 rad] for cross-sections corresponding to particular control points on the footbridge

\begin{tabular}{|c|c|c|c|c|c|c|c|c|}
\hline $\begin{array}{c}\text { Cross-section } \\
\text { at point } \\
\text { (through } \\
\text { node) }\end{array}$ & $\mathbf{A}$ & $\mathbf{B}$ & $\mathbf{C}$ & $\mathbf{D}$ & $\mathbf{E}$ & $\mathbf{F}$ & $\mathbf{G}$ & $\mathbf{H}$ \\
\cline { 2 - 9 } & -0.03 & 0.00 & 0.03 & 0.06 & 0.00 & -0.03 & 0.08 & $\mathbf{0 . 2 0}$ \\
\hline $\mathbf{0 1}(\mathbf{8})$ & -0.08 & -0.06 & 0.00 & 0.00 & 0.03 & 0.06 & 0.14 & 0.06 \\
\hline $\mathbf{0 2}(\mathbf{1})$ & 0.11 & 0.08 & 0.14 & 0.14 & $\mathbf{- 0 . 2 0}$ & 0.08 & $\mathbf{0 . 1 7}$ & 0.00 \\
\hline $\mathbf{0 3}(\mathbf{2})$ & $\mathbf{- 0 . 4 8}$ & $\mathbf{- 0 . 3 7}$ & 0.17 & 0.14 & 0.06 & 0.03 & -0.08 & -0.03 \\
\hline $\mathbf{0 4}(\mathbf{3})$ & & & & & & & & \\
\hline
\end{tabular}




\begin{tabular}{|c|c|c|c|c|c|c|c|c|}
\hline $\mathbf{0 5}(\mathbf{4})$ & -0.06 & -0.06 & 0.14 & $\mathbf{0 . 5 4}$ & 0.11 & -0.03 & -0.03 & -0.14 \\
\hline $\mathbf{0 6}(\mathbf{1 0 )}$ & 0.23 & 0.11 & 0.14 & 0.25 & 0.03 & $\mathbf{- 0 . 1 7}$ & -0.08 & -0.03 \\
\hline $\mathbf{0 7}(\mathbf{1 1})$ & 0.00 & -0.11 & -0.03 & 0.11 & -0.08 & -0.11 & -0.03 & -0.03 \\
\hline $\mathbf{0 8}(\mathbf{1 2})$ & 0.28 & 0.03 & $\mathbf{0 . 2 3}$ & 0.11 & -0.06 & -0.08 & -0.06 & -0.06 \\
\hline $\mathbf{0 9 ( 1 3 )}$ & -0.23 & -0.20 & -0.17 & -0.25 & 0.06 & 0.08 & 0.06 & 0.06 \\
\hline $\mathbf{1 0}(\mathbf{1 4})$ & 0.00 & -0.08 & 0.06 & 0.14 & -0.08 & 0.00 & 0.00 & 0.00 \\
\hline
\end{tabular}

It can be seen that the greatest rotation is present in cross-sections corresponding to control points 04 and 05 , when loads A, B, and D are applied (in other words, the greatest rotation is present on the half of the footbridge closer to Jagiellońska street, with loads placed on this side).

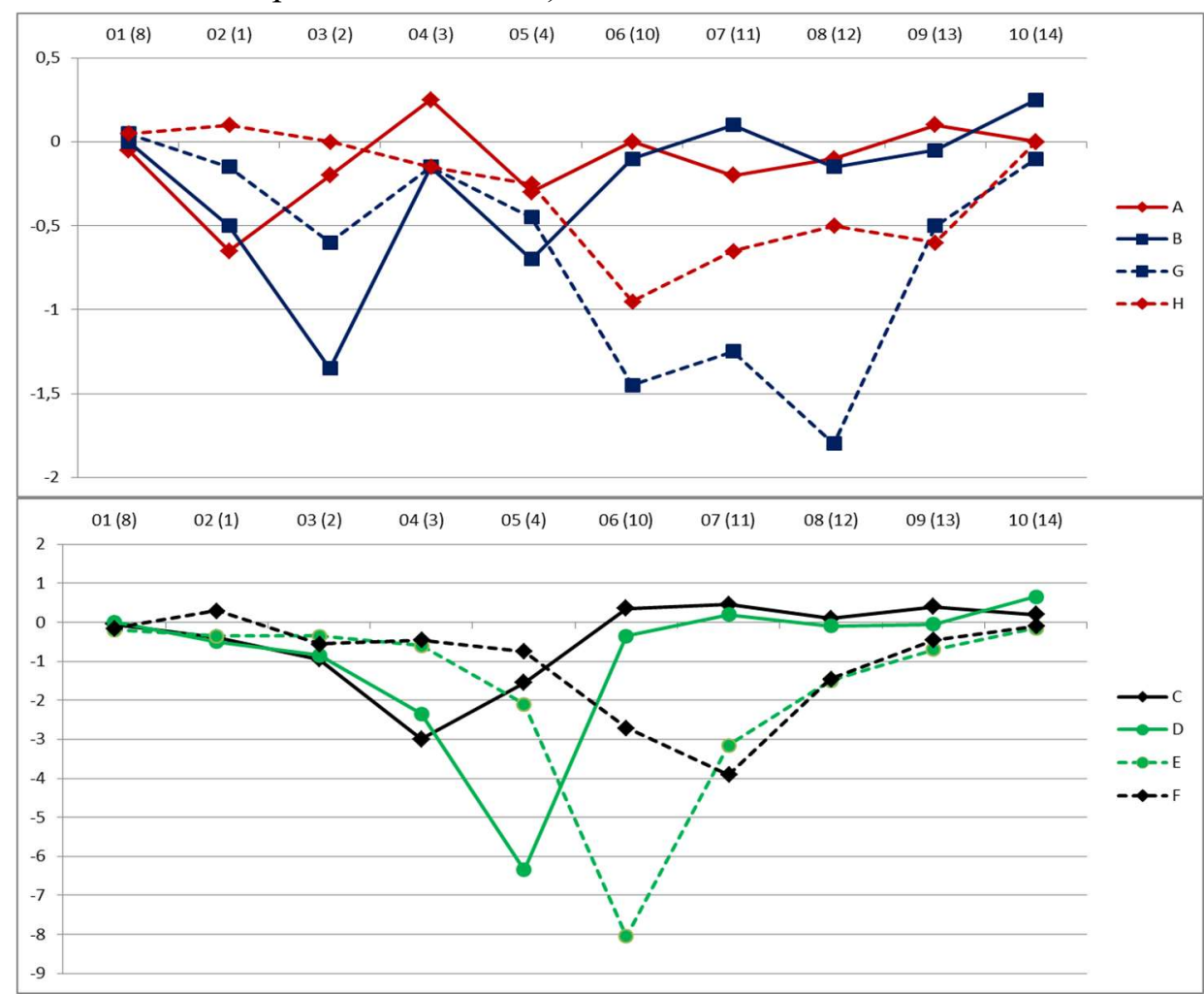

Fig. 6. Distribution of average displacements along the footbridge axis for particular load patterns

During analysis of distribution of measured vertical displacements in the footbridge along its axis, average values of these displacements in particular 
cross-sections have been used. Displacements for the entire structure have been presented in the following chart (Fig. 6).

Lines of the same colours in Fig. 6 should be close to symmetrical, i.e. the line for load A (red solid) should be symmetrical to the line for load H (red dotted), the line for B (dark blue solid) should be symmetrical to the line for $\mathrm{G}$ (dark blue dotted), etc. The anticipated symmetry is not present. What is observed instead is that values of footbridge displacements occurring when load is applied at the side closer to Toruńska street (load patterns $\mathrm{E} \div \mathrm{H}$ ) are greater than values of displacements occurring when load is applied at the side closer to Jagiellońska street (load patterns $A \div D$ ).

In addition, relationship between values of vertical displacements that were measured and those calculated using FEM were analysed. The analysis included average displacements and referred to the footbridge axis.

a) b)

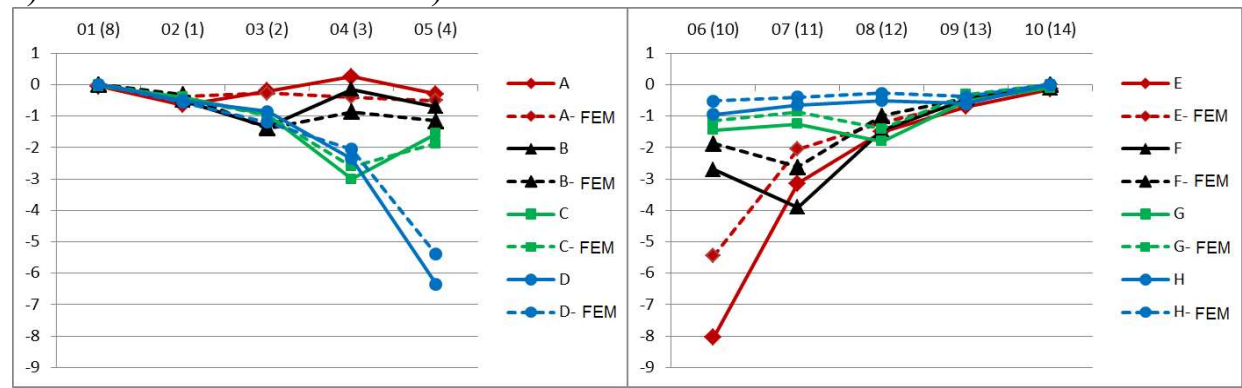

Fig. 7. Comparison of measured (average) displacements and calculated displacements,

a) for the half of the footbridge closer to Jagiellońska street, with load on that side,

b) for the half of the footbridge closer to Torunska street, with load on that side

Comparing solid and dotted lines of the same colour, it is evident that values of measured displacements are greater than values of displacements calculated using the FEM algorithm. These differences are greater on the half of the bridge closer to Toruńska street, which is a result of their asymmetric distribution shown in Fig. 7.

\section{CONCLUSION}

1. In theoretical calculations, footbridge displacements in all cases were achieved only on the half where load had been applied. It is reasonable as displacements of particular segments of the main span are the result of elongation of stay cables and displacement of top nodes of pylons (there are no such displacements or deformations noted at the unloaded part of the footbridge). The map of measured displacements is different from that of 
theoretical displacements. Applying loads on the footbridge caused all of its segments to displace. It must be acknowledged that the actual nature of work of the footbridge is different from that assumed in the computer-generated model (static diagram). It can be speculated that the differences pertain to behaviour of footbridge structure nodes. It is likely that connections between deck segments do not have a full joint-like character (are characterised by certain rigidity) or the expansion joint between parts of the deck does not fulfil its task.

2. The anticipated symmetry of measured displacements of the footbridge has not been observed (this is true for the longitudinal symmetry and the lateral symmetry within the structural system). In particular, it pertains to the lateral direction, where the footbridge tends to rotate. Rotation differs in individual cross-sections, which causes slight bending of deck segments. It is surprising that in some cross-sections of the footbridge displacements tend to have opposite signs (i.e. one edge of the footbridge lowers, whereas the other moves up) - it can be concluded after analysing displacements shown in Table 1. Such a displacement map can be caused by e.g. improper adjustment of the footbridge (geometry-wise), wear and tear of its structure (e.g. excessive and irregularly distributed wearing of nodes), presence of unknown, diverse rigidity of nodes that should in theory be joint-like, and creation of internal forces within the nodes.

3. The map of displacements in the footbridge measured during the study turned out to be so complex, or even surprising, and different from theoretical displacements that its mechanics could not be fully understood. Further studies and analyses are needed, such as:

- measuring displacement of other characteristic nodes of the footbridge (e.g. top nodes of pylons),

- estimation of tension in the stay cables,

- additional numerical analyses, including analyses allowing for the rigidity of nodes considered to be joint-like up until now and subsequent analyses employing spatial models.

\section{REFERENCES}

1. Bujarkiewicz A, Sztubecki J., Sztubecka M.: Badania przemieszczeń konstrukcji mostowych $z$ wykorzystaniem stacji laserowej, Materiały budowlane $7 / 2014$.

2. Catbas F. N., Kijewski-Korea T., Aktan A.E.: Structural Identification of Constructed Systems, Reston Virginia, ASCE 2013. 
3. Dudek K.: Brda i Kanat Bydgoski. Volume 2 of the Mosty z biegiem rzek series. Związek Mostowców Rzeczypospolitej Polskiej, Oddział KujawskoPomorski, 2006.

4. Karbhari V. M., Ansari F.: Structural Health Monitoring of Civil Infrastructure Systems, Cambridge, Woodhead Publishing 2009.

5. Mrówczyńska M., Gibowski S.: Indicating vertical deviation of historical buildings using geodetic methods - case study of brick and wood tower in Nowe Miasteczko, Civil and Environmental Engineering Reports, Volume 22, 2016, Pages 127-135.

6. Sobczak-Piąstka J., Janiak T., Niespodziana A., Olejniczak M., Grabowski A.: Diagnostyka wiaduktu drogowego, Materiały budowlane $7 / 2016$

7. The Building Law Act of 7 July 1994 (Journal of Laws of 1994, no. 89, item 414, amended).

\section{ANALIZA PRZEMIESZCZEŃ PIONOWYCH KŁADKI ESPERANTO W BYDGOSZCZY}

\section{Streszczenie}

Przedmiotem przeprowadzonych badań jest kładka przez rzekę Brdę w Bydgoszczy. W ramach badań wykonano pomiary przemieszczeń kładki przy przyłożonym próbnym obciążeniu. $\mathrm{W}$ artykule przedstawiono wyniki przeprowadzonych pomiarów oraz porównano je $\mathrm{z}$ wynikami teoretycznymi otrzymanymi przy zastosowaniu metody elementów skończonych (MES). Na tej podstawie stwierdzono rozbieżności pomiędzy rzeczywistą pracą konstrukcji a symulacjami numerycznymi. We wnioskach podjęto próbę wyjaśnienia przyczyn zaobserwowanych różnic oraz wskazano kierunek dalszych badań.

Słowa kluczowe: most wantowy, przemieszczenia, model MES

Editor received the manuscript: 27.11.2017 